\title{
In vitro fermentation properties of pectins and enzymatic-modified pectins obtained from different renewable bioresources
}

Article

Accepted Version

Creative Commons: Attribution-Noncommercial-No Derivative Works 4.0

Ferreira-Lazarte, A., Kachrimanidou, V., Villamiel, M., Rastall, R. A. and Moreno, F. J. (2018) In vitro fermentation properties of pectins and enzymatic-modified pectins obtained from different renewable bioresources. Carbohydrate Polymers, 199. pp. 482-491. ISSN 0144-8617 doi:

https://doi.org/10.1016/j.carbpol.2018.07.041 Available at https://centaur.reading.ac.uk/79091/

It is advisable to refer to the publisher's version if you intend to cite from the work. See Guidance on citing.

Published version at: http://dx.doi.org/10.1016/j.carbpol.2018.07.041

To link to this article DOI: http://dx.doi.org/10.1016/j.carbpol.2018.07.041

Publisher: Elsevier

All outputs in CentAUR are protected by Intellectual Property Rights law, including copyright law. Copyright and IPR is retained by the creators or other copyright holders. Terms and conditions for use of this material are defined in the End User Agreement. 


\section{CentAUR}

Central Archive at the University of Reading

Reading's research outputs online 


\section{$1 \quad$ In vitro fermentation properties of pectins and enzymatic-modified}

pectins obtained from different renewable bioresources

3 Alvaro Ferreira-Lazarte ${ }^{1}$, Vasiliki Kachrimanidou ${ }^{2}$, Mar Villamiel ${ }^{1}$, Robert A. Rastall ${ }^{2}$,

$5{ }^{1}$ Instituto de Investigación en Ciencias de la Alimentación, CIAL (CSIC-UAM).

6 C/Nicolás Cabrera, 9, Campus de la Universidad Autónoma de Madrid, 28049 Madrid,

7 Spain

$8{ }^{2}$ Department of Food and Nutritional Sciences, The University of Reading, PO Box

9 226, Whiteknights, Reading RG6 6 AP, UK

$11 *$ *Author to whom correspondence should be addressed: E-mail: javier.moreno@csic.es

12 Tel: +34910017948 


\section{Abstract}

15 The suitability of artichoke and sunflower by-products as renewable sources of pectic 16 compounds with prebiotic potential was evaluated by studying their ability to modulate

17 the human faecal microbiota in vitro. Bacterial populations and short-chain fatty acid 18 (SCFA) production were measured. Reduction of the molecular weight of artichoke 19 pectin resulted in greater stimulation of the growth of Bifidobacterium, Lactobacillus 20 and Bacteroides/Prevotella, whilst this effect was observed only in 21 Bacteroides/Prevotella for sunflower samples. In contrast, the degree of methylation did 22 not have any impact on fermentability properties or SCFA production, regardless of the 23 origin of pectic compounds. Although further in vivo studies should be conducted, 24 either pectin or enzymatically-modified pectin from sunflower and artichoke by25 products might be considered as prebiotic candidates for human consumption showing 26 similar ability to promote the in vitro growth of beneficial gut bacteria as compared to 27 well-recognized prebiotics such as inulin or fructo-oligosaccharides.

29 Keywords: pectin, modified pectin, in vitro fermentation, prebiotic properties, SCFA, 30 gut microbiota. 
One of the most complex polysaccharides that exist in the cell wall of all higher plants is pectin (Kačuráková, Capek, Sasinková, Wellner, \& Ebringerová, 2000). Pectin is not a single structure and comprises of a family of plant cell wall polysaccharides that contain galacturonic acid (GalA) linked at $\alpha-1,4$ positions. It mainly consists of a GalArich backbone, known as homogalacturonan $(\mathrm{HG} \approx 65 \%)$ which is partially methylesterified in C-6 and O-acethyl-esterified in positions 2 and 3 (Mohnen, 2008). Rhamnose residues interrupt the HG structure to form rhamnogalacturonan I (RG-I $\approx$ $20-35 \%$ ) which is based on a backbone consisting of a repeating disaccharide of GalA and rhamnose residues. In addition, some rhamnose residues may contain sidechains consisting of $\alpha$-L-arabinose and/or $\beta$-D-galactose (arabinans, galactans and arabinogalactans). RG-II constitutes $\approx 2-10 \%$ of pectin and is the most complex, but is also believed to be the most conserved part of pectin molecules. RG-II has a HG backbone and is branched with rhamnose and other minor sugars such as fucose, glucuronic acid and methyl-esterified glucuronic acid among other rare carbohydrates such as apiose, 2-O-methylxylose, and 2-O-methylfucose (Holck, Hotchkiss, Meyer, Mikkelsen, \& Rastall, 2014; Noreen et al., 2017).

The biological effects of pectins have been mainly studied on in vitro assays and they are highly fermentable dietary fibres. Furthermore, pectic-oligosaccharides (POS) have been proposed as a new class of prebiotics capable of exerting a number of healthpromoting effects (Olano- Martin, Gibson, \& Rastall, 2002). These benefits include a desirable fermentation profile in the gut (Gómez, Gullón, Yáñez, Schols, \& Alonso, 2016), potential in vitro anti-cancer properties (Maxwell et al., 2015), potential for cardiovascular protection (Samuelsson et al., 2016), as well as antibacterial, antiinflammatory and antioxidant properties, among others (Míguez, Gómez, Gullón, 
57 Gullón, \& Alonso, 2016). Nevertheless, the details of the underlying mechanisms are still largely unknown and additional studies are needed on the structure-function interrelationship, as well as on the claimed effects caused by POS in humans (Gullón et al., 2013).

Apart from POS, whose degree of polymerization range from 3 to 10 , during the past few years there has been a flourishing interest towards pectin derivatives, especially the so-called "modified pectins" (MP), a term standing for pectin-derived, water-soluble polysaccharide of lower molecular weight $(\mathrm{Mw})$ than the original pectin and, normally, produced from citrus peel and pulp (Holck et al., 2014). These compounds can be obtained from pectins in their native form using chemical and enzymatic treatments, which produce lower $\mathrm{Mw} \mathrm{HG}$ and fragments enriched in $\mathrm{RG}$ (Morris, Belshaw, Waldron, \& Maxwell, 2013). The break-down of pectins not only leads to modification of their physico-chemical and gelling properties (Ngouémazong, Christiaens, Shpigelman, Van Loey, \& Hendrickx, 2015), but also modulation of their bioactivity (Morris et al., 2013).

There are several in vitro and in vivo studies on the ability of MP to inhibit tumour growth and metastasis (Morris et al., 2013; Nangia-Makker et al., 2002; Park, Park, Hong, Suh, \& Shin, 2017). Citrus MP inhibits in vitro and in vivo angiogenesis in different types of cancer by blocking the association of galectin-3 to its receptors (Zhang, Xu, \& Zhang, 2015). Other beneficial health properties might include the reduction of atherosclerotic lesions ( $\mathrm{Lu}$ et al., 2017), anti-inflammatory and antioxidant properties (Popov \& Ovodov, 2013; Ramachandran, Wilk, Melnick, \& Eliaz, 2017) or immunostimulatory properties (Vogt et al., 2016). However, most of these studies were performed using cell cultures or in mice and extrapolation of the results to human or clinical investigations should be considered with caution. 
Nonetheless, only a few recent studies have addressed the prebiotic potential of MP in terms of the fermentation properties. A slight or no increase was observed in the faecal lactobacilli count during an in vivo study with rats fed with citrus MP (OdunAyo, Mellem, \& Reddy, 2017). Di et al. (2017) compared five structurally different citrus pectic samples ( 3 of them were POS and 2 were MP) and found that two POS and one MP exhibited bifidogenic effects with similar fermentabilities in human faecal cultures. These authors concluded that $\mathrm{Mw}$ and degree of methylation did not affect their bifidogenic properties; however, structural diversity in pectic compounds is possible as long as significant arabino- and galacto-oligosaccharide content is present. Fanaro et al. (2005) investigated the effect of acidic oligosaccharides from pectin on intestinal flora and stool characteristics in infants, showing that they were well tolerated as ingredient in infant formulae but did not affect intestinal microecology.

To the best of our knowledge, the fermentation and prebiotic properties of pectin derived from artichoke (Sabater, Corzo, Olano, \& Montilla, 2018) and sunflower (Muñoz-Almagro, Rico-Rodríguez, Wilde, Montilla, \& Villamiel, 2018b) by-products have not been explored. In the case of artichoke, only one previous study showed a selective growth of two specific strains, i.e. Lactobacillus plantarum 8114 and Bifidobacterium bifidum ATCC 11863 which was ascribed to the combination of its high inulin and low methylated pectin contents (Fissore, Santo Domingo, Gerschenson, \& Giannuzzi, 2015). Also, Costabile et al. (2010) reported, in a double-blind, cross-over study carried out in healthy adults, a pronounced prebiotic effect (i.e., increasing of bidifobacteria and lactobacilli) of a very-long-chain inulin derived from artichoke on the human faecal microbiota composition. The lack of knowledge of potential alternative sources of active pectic compounds for human consumption is surprising as previous studies reported that structure and composition can make a significant difference to the 
107 fermentation properties (Onumpai, Kolida, Bonnin, \& Rastall, 2011). Thus, bifidogenic properties seem to highly depend on the composition and structure of pectins, with neutral sugar content and GalA:Rha ratio being critical factors (Di et al., 2017).

In this context, considering the structural diversity of pectins dependent on their origin, the aim of this study was to evaluate the effect of a variety of pectins and enzymatic-modified pectins from different sources (in particular, citrus, sunflower and artichoke) on the profile changes in human faecal microbiota population and fermentation metabolites, i.e. short-chain fatty acids.

\section{Materials and methods}

\subsection{Raw material}

Sunflower by-products based on heads and leftover stalks and artichoke by-products derived from external bracts, leaves and stems, were supplied by Syngenta AG and Riberebro S.L. (Spain), respectively. Prior to experiments, raw material was ground with a knife mill to particle size $<500 \mu \mathrm{m}$. Commercial citrus pectin (trade name Ceampectin $^{\circledR}$, ESS-4400) was kindly provided by CEAMSA (Porriño, Pontevedra, Spain).

\subsection{Pectin extraction and modification}

Sunflower pectin was extracted from $1 \mathrm{~kg}$ of dried substrate by suspending in 20 L of sodium citrate $(0.7 \%)$ at $52^{\circ} \mathrm{C}, \mathrm{pH} 3.2$ for 184 min under agitation and the residue was precipitated with ethanol and then freeze-dried (Muñoz-Almagro et al. 2018b). Artichoke pectin was extracted using a cellulase from Trichoderma reesei (Celluclast $^{\circledR}$ 1.5 L, Novozymes, Bagsvaerd, Denmark) in an orbital shaker at $50{ }^{\circ} \mathrm{C}$, pH 5 with constant shaking (200 rpm) following the method described by Sabater et al. (2018). 
131 After hydrolysis, samples were centrifuged $\left(1,300 \times \mathrm{x}\right.$ for $10 \mathrm{~min}$ at $\left.4{ }^{\circ} \mathrm{C}\right)$ and supernatants were filtered through cellulose paper. Residues were washed and precipitated in $70 \%$ ethanol, centrifuged $(1,200 \mathrm{x} g, 20 \mathrm{~min})$ and then freeze-dried. Extraction yield of pectin (expressed as percentage) represents the amount of pectin extracted from $100 \mathrm{~g}$ of initial dried raw material, being $10.0 \%$ and $22.1 \%$ the obtained values for sunflower and artichoke pectin, respectively.

The extracted sunflower and artichoke pectins, as well as the commercial citrus pectin were then subjected to an enzymatic treatment using a commercial cellulase from Aspergillus niger (Sigma Aldrich, Steinheim, Germany) with pectinolytic activity to reduce their Mw. Then, the resulting material was transferred to a continuous membrane reactor to separate the modified pectin from oligosaccharides and free sugars formed (Olano-Martin, Mountzouris, Gibson \& Rastall, 2001). The reactor consisted of an ultrafiltration dead-end stirred cell (model 8000, Amicon, Watford, U.K.) where the substrate was added and then pushed from a pressurized feed tank filled with water at a rate matching the permeate flow rate. All filtrations were carried out with an Ultracel ${ }^{\circledR}$ ultrafiltration disk membrane, with a Mw cut-off (MWCO) of $3 \mathrm{kDa}$ and a diameter of $76 \mathrm{~mm}$ as determined by the manufacturers. Checking of absence of low molecular weight carbohydrates in the ultrafiltered samples was accomplished by the analysis of the resulting retentates and permeates by SEC-ELSD following the method described in subsection 2.3.2. All pectin and MP samples were free from monosaccharides, as well as oligosaccharides below $10 \mathrm{kDa}$ (Figure 1).

\subsection{Characterisation of pectin and enzymatic-modified pectin samples}

\subsubsection{Monosaccharide analysis}

Monosaccharide analysis was performed after the acid hydrolysis of samples with 2 $\mathrm{M}$ trifluoroacetic acid (TFA) at $110{ }^{\circ} \mathrm{C}$ for $4 \mathrm{~h}$. After that, released monosaccharides 
were analysed by gas chromatography (GC) carried out with an Agilent Technologies gas chromatograph (7890A) equipped with a flame ionisation detector (FID). Prior to GC analysis, trimethylsilyl oximes (TMSO) of monosaccharides were formed (Cardelle-Cobas, Martínez-Villaluenga, Sanz, \& Montilla, 2009). $500 \mu \mathrm{L}$ of hydrolysed samples were evaporated to remove the acid and then $400 \mu \mathrm{L}$ of phenyl- $\beta$-glucoside $(0.5 \mathrm{mg} / \mathrm{mL})$ used as internal standard (I.S.) were added. Afterward, the mixture was dried at $40{ }^{\circ} \mathrm{C}$ in a rotary evaporator (Büchi Labortechnik AG, Flawil, Switzerland). Sugar oximes were formed by adding $250 \mu \mathrm{L}$ hydroxylamine chloride $(2.5 \%)$ in pyridine and heating the mixture at $70{ }^{\circ} \mathrm{C}$ for $30 \mathrm{~min}$. Subsequently, the oximes obtained in this step were silylated with hexamethyldisylazane $(250 \mu \mathrm{L})$ and TFA (25 $\mu \mathrm{L}$ ) at $50{ }^{\circ} \mathrm{C}$ for $30 \mathrm{~min}$. Derivatisation mixtures were centrifuged at $6,700 \times \mathrm{g}$ for $2 \mathrm{~min}$ and supernatants were injected in the GC-FID.

Analyses were carried out using a DB-5HT capillary column (15 m x $0.32 \mathrm{~mm}$ x $0.10 \mu \mathrm{m}, \mathrm{J} \& \mathrm{~W}$ Scientific, Folson, California, USA). Nitrogen was used as carrier gas at a flow rate of $1 \mathrm{~mL} / \mathrm{min}$. Injector and detector temperatures were 280 and $385{ }^{\circ} \mathrm{C}$, respectively. The oven temperature was programmed from 150 to $380{ }^{\circ} \mathrm{C}$ at a heating ratio of $1{ }^{\circ} \mathrm{C} / \mathrm{min}$ until $165{ }^{\circ} \mathrm{C}$ and then up to $300{ }^{\circ} \mathrm{C}$ at a heating rate of $10{ }^{\circ} \mathrm{C} / \mathrm{min}$. Injections were made in the split mode (1:5).

Data acquisition and integration were done using Agilent ChemStations software (Wilmington, DE, USA). Response factors were calculated after duplicate analysis of standard solutions (glucose, mannose, rhamnose, arabinose, galactose, GalA and xylose) over the expected concentration range in samples, $(0.01-2 \mathrm{mg})$ and IS (0.2 $\mathrm{mg})$. 


\subsubsection{Estimation of the molecular weight $(\mathrm{Mw})$}

Estimation of Mw was carried out by Size Exclusion Chromatography (SEC) according to the method described by (Muñoz-Almagro, Rico-Rodriguez, Villamiel, \& Montilla, 2018a). The analysis was performed on a LC Agilent Technologies 1220 Infinity LC System 1260 (Agilent Technologies, Germain), equipped with two consecutive TSK-GEL columns (G5000 PWXL, 7.8 x $300 \mathrm{~mm}$, particle size $10 \mu \mathrm{m}$, G2500 PW $\mathrm{XL}_{1}, 7.8 \times 300 \mathrm{~mm}$, particle size $6 \mu \mathrm{m}$ ) connected in series with a TSK-Gel guard column $(6.0 \mathrm{~mm} \times 400 \mathrm{~mm})$ (Tosoh Bioscience, Stuttgart, Germany). Samples (20 $\mu \mathrm{L}$ ) were eluted with $0.1 \mathrm{M} \mathrm{NaCl}$ at a flow rate of $0.5 \mathrm{~mL} / \mathrm{min}$ for $50 \mathrm{~min}$ at $30^{\circ} \mathrm{C}$. The eluent was monitored with an Evaporative Light Scattering Detector (ELSD) (Boeblingen, Germain) at $30{ }^{\circ} \mathrm{C}$. Pullulans of $\mathrm{Mw}$ 805, 200, 10, 3 and $0.3 \mathrm{kDa}$ were used as standards to calibration. All the Mw values specified were weight-average.

\subsubsection{Estimation of the degree of methylation}

Degree of methylation of samples was determined by Fourier transform infrared spectroscopy (FTIR). KBr discs were prepared mixing the pectin and enzymaticmodified pectin samples with $\mathrm{KBr}(1: 100)$ and pressing. FTIR spectra Bruker IFS66v (Bruker, US) were collected in absorbance mode in the frequency range of 400-4000 $\mathrm{cm}^{-1}$, at a resolution of $4 \mathrm{~cm}^{-1}$ (mid infrared region) with 250 co-added scans. The degree of methylation was determined as the average of the ratio of the peak area at $1747 \mathrm{~cm}^{-1}$ (COO-R) and $1632 \mathrm{~cm}^{-1}\left(\mathrm{COO}^{-}\right)$as previously described (Singthong, Cui, Ningsanond, \& Douglas Goff, 2004). 
2.4 Determination of in vitro fermentation properties and prebiotic activity

\subsubsection{Faecal Inocula}

Faecal samples from five healthy adults ( 2 male, 3 female, mean age of $30.6 \pm 4.2$ years old) who had not consumed prebiotic or probiotic products, nor had received antibiotic treatment within 3 months before study were obtained in situ. Samples were kept in an anaerobic cabinet and used within a maximum of 15 min after collection.

Faecal samples were diluted $(10 \% \mathrm{w} / \mathrm{w})$ in anaerobic phosphate-buffered saline (PBS; $0.1 \mathrm{~mol} / \mathrm{L}, \mathrm{pH} 7.4$, Oxoid, Basingstoke, UK) and homogenised in a stomacher (Stomacher 400, Seward, UK) at normal speed for 2 min.

\subsubsection{In vitro batch fermentations}

Sterile stirred batch culture fermentation systems were set up and aseptically filled with a volume of sterile, basal medium: (per litre) $2 \mathrm{~g}$ peptone water, $2 \mathrm{~g}$ yeast extract, $0.1 \mathrm{~g} \mathrm{NaCl}, 0.04 \mathrm{~g} \mathrm{~K}_{2} \mathrm{HPO}_{4}, 0.04 \mathrm{~g} \mathrm{KH}_{2} \mathrm{PO}_{4}, 0.01 \mathrm{~g} \mathrm{MgSO}_{4} \cdot 7 \mathrm{H}_{2} \mathrm{O}, 0.01 \mathrm{~g} \mathrm{CaCl}_{2} \cdot 6 \mathrm{H}_{2} \mathrm{O}$, $2 \mathrm{~g} \mathrm{NaHCO}_{3}, 2 \mathrm{~mL}$ Tween 80, $0.05 \mathrm{~g}$ haemin, $10 \mu \mathrm{L}$ vitamin $\mathrm{K} 1,0.5 \mathrm{~g}$ L-cysteine $\mathrm{HCl}$, $0.5 \mathrm{~g}$ bile salts and $4 \mathrm{~mL}$ resazurin $(0.25 \mathrm{~g} / \mathrm{L})$. Medium was sterilised at $120{ }^{\circ} \mathrm{C}$ for 30 min before aseptically dispensing into the sterile fermenters. Sterile stirred fermenters were filled with $9 \mathrm{~mL}$ of autoclaved basal medium and were gassed overnight by constant sparging oxygen-free nitrogen to maintain anaerobic conditions. $100 \mathrm{mg}$ of substrates were added (final concentration of $1 \%(\mathrm{w} / \mathrm{v})$ ) to the respective fermentation just prior to the addition of the faecal inoculum $(1 \mathrm{~mL})$. The temperature was maintained at $37{ }^{\circ} \mathrm{C}$ using a water jacket and the $\mathrm{pH}$ was maintained between 6.7 and 6.9 using an automated pH controller (Fermac 260; Electrolab, Tewkesbury, UK). The batch cultures were run for a period of $48 \mathrm{~h}$ and samples were taken from each vessel at 0 and $24 \mathrm{~h}$ for bacterial enumeration by fluorescent in situ hybridisation (FISH) and at $0,10,24,36$ and $48 \mathrm{~h}$ for SCFA by GC-FID. 3 extra vessels with inulin, 
224 fructooligosaccharides (FOS) and no added carbohydrate source were also included as

225 positive and negative control, respectively.

\subsubsection{Short-chain fatty acid (SCFA) analysis}

Before chemical analysis, samples from each fermentation time were centrifuged at $13,000 \times \mathrm{g}$ for $10 \mathrm{~min}$ to obtain the supernatant. The clear solutions were kept at $-20{ }^{\circ} \mathrm{C}$ until analysis. SCFA analysis was carried out using GC-FID based on the method described by (Richardson, Calder, Stewart, \& Smith, 1989). Before analysis, samples were thawed on ice and then vortexed. After that, $400 \mu \mathrm{L}$ of each sample were taken into a glass tube and $25 \mu \mathrm{L}$ of 2-ethylbutyric acid (0.1 M) (IS) was added. Following that, $250 \mu \mathrm{L}$ of concentrated $\mathrm{HCl}$ and $1.5 \mathrm{~mL}$ of diethyl ether were added and the solution was mixed $1 \mathrm{~min}$ and centrifuged $10 \mathrm{~min}$ at $2,000 \times \mathrm{g} .400 \mu \mathrm{L}$ of the upper layer (ether layer) was transferred to a GC screw-cap vial and $50 \mu \mathrm{L}$ of $N$-(tertbutyldimethylsilyl)-N-methyltrifluoroacetamide (MTBSTFA) was added and leave $72 \mathrm{~h}$ to produce fully derivatisation.

A 5890 Series II Gas Chromatograph (Hewlett Packard) fitted with a Rtx-1 10 m x $0.18 \mathrm{~mm}$ column with a $0.20 \mu \mathrm{m}$ coating (Crossbond $100 \%$ dimethyl polysiloxane; Restek) was used for analysis. Helium was used as carrier gas at a flow rate of 0.7 $\mathrm{mL} / \mathrm{min}$. Injector and detector temperatures were $275{ }^{\circ} \mathrm{C}$. Oven temperature was programmed from $63{ }^{\circ} \mathrm{C}$ for $3 \mathrm{~min}$ and then heated to $190{ }^{\circ} \mathrm{C}$ at a heating ratio of 3 ${ }^{\circ} \mathrm{C} / \mathrm{min}$ and held at $190{ }^{\circ} \mathrm{C}$ for 3 min. Injections were made in the split mode (100:1).

244 SCFA standards analysis was also carried out to quantify concentrations of all compounds. 
247 Enumeration of the target faecal bacteria groups was achieved by FISH with 248 fluorescently labelled 16S rRNA probes according to the method described by (Wagner, 249 Hornt, \& Daims, 2003). Briefly, $375 \mu \mathrm{L}$ aliquots were obtained from each fermenter 250 and were mixed with $1.125 \mathrm{~mL} \mathrm{4 \%} \mathrm{(w/v),} \mathrm{ice-cold} \mathrm{paraformaldehyde} \mathrm{and} \mathrm{fixed} \mathrm{for} \mathrm{4-10}$ $251 \mathrm{~h}$ at $4{ }^{\circ} \mathrm{C}$. Fixed cells were then centrifuged at $13,000 \times \mathrm{g}$ for $5 \mathrm{~min}$ and washed twice on $2521 \mathrm{~mL}$ cold filter-sterilised PBS (0.1 M). The washed cells were then resuspended in 150 $\mu \mathrm{L}$ PBS and $150 \mu \mathrm{L}$ of absolute ethanol $(99 \%)$ and stored at $-20^{\circ} \mathrm{C}$ until analysis.

To obtain an appropriate number of fluorescent cells in each field of view of the microscope, samples to hybridise were then diluted in a suitable volume of PBS with $1 \%(\mathrm{v} / \mathrm{v})$ of sodium dodecyl sulphate, and $20 \mu \mathrm{L}$ of the dilution was added to each well of a six-well polytetrafluoroethylene/poly-L-lysine-coated slide (Tekdon Inc., Myakka City, USA). Samples were dried at $48-50{ }^{\circ} \mathrm{C}$ for $15 \mathrm{~min}$ in a desktop plate incubator and dehydrated in an alcohol series (50, 80 and 96\% (v/v) ethanol, 2 min each) and placed again at $48-50{ }^{\circ} \mathrm{C}$ to evaporate the excess of ethanol before adding the hybridisation solution. $50 \mu \mathrm{L}$ of hybridisation solution (per $1 \mathrm{~mL} ; 5 \mathrm{M} \mathrm{NaCl} 180 \mu \mathrm{L}, 1 \mathrm{M}$ Tris/HCl 20 $\mu \mathrm{L}, \mathrm{ddH}_{2} \mathrm{O} 799 \mu \mathrm{L}, 1 \mu \mathrm{L}$ SDS $10 \%$ (w/v) and $100 \mu \mathrm{L}$ of probe) was added to each well and left to hybridise for $4 \mathrm{~h}$ in a microarray hybridisation incubator (Grant-Boekel, UK) at $46-50{ }^{\circ} \mathrm{C}$ depending on the probe. After hybridisation, slides were washed in $50 \mathrm{~mL}$ washing buffer (5 M NaCl $9 \mathrm{~mL}, \mathrm{ddH}_{2} \mathrm{O} 40 \mathrm{~mL}$ and $1 \mathrm{M}$ Tris/HCl $\left.1 \mathrm{~mL}\right)$ for $15 \mathrm{~min}$ and dipped in cold distilled water for 2-3 seconds. Slides were then dried with compressed $\mathrm{N}_{2}$ and a drop of PVA-DABCO antifade (polyvinyl alcohol mounting medium with 1,4-diazabicyclo (2.2.2) octane) was added onto each well. A coverslip 269 (20 mm, thickness no. 1; VWR) was placed on each slide and cell numbers of 270 microorganisms were determined by direct counting under an epifluorescence 
271 microscope (Eclipse 400; Nikon, Surrey, UK) with Fluor 100 lens. A total of 15 random

272 fields of view were counted for each well.

273 The oligonucleotide probes used and conditions for each one are detailed in Table $\mathbf{1}$

274 These probes were selected to account for major bacterial groups in the Actinobacteria

275 (Bif164), Bacteroidetes (Bac303), and Firmicutes (Lab158, Erec482, Chis150) phyla.

\section{$276 \quad 2.5$ Statistical Analysis}

277 Statistical analysis was performed using SPSS for Windows, version 23.0. One-way 278 analysis of variance (ANOVA) and Tukey's post hoc test was used to determine 279 significant differences among the bacterial group populations and organic acid 280 concentrations among the different substrates. Differences were considered significant 281 at $p<0.05(\mathrm{n}=5)$. 


\section{Table 1}

Oligonucleotide probes used in this study for FISH enumeration of bacteria.

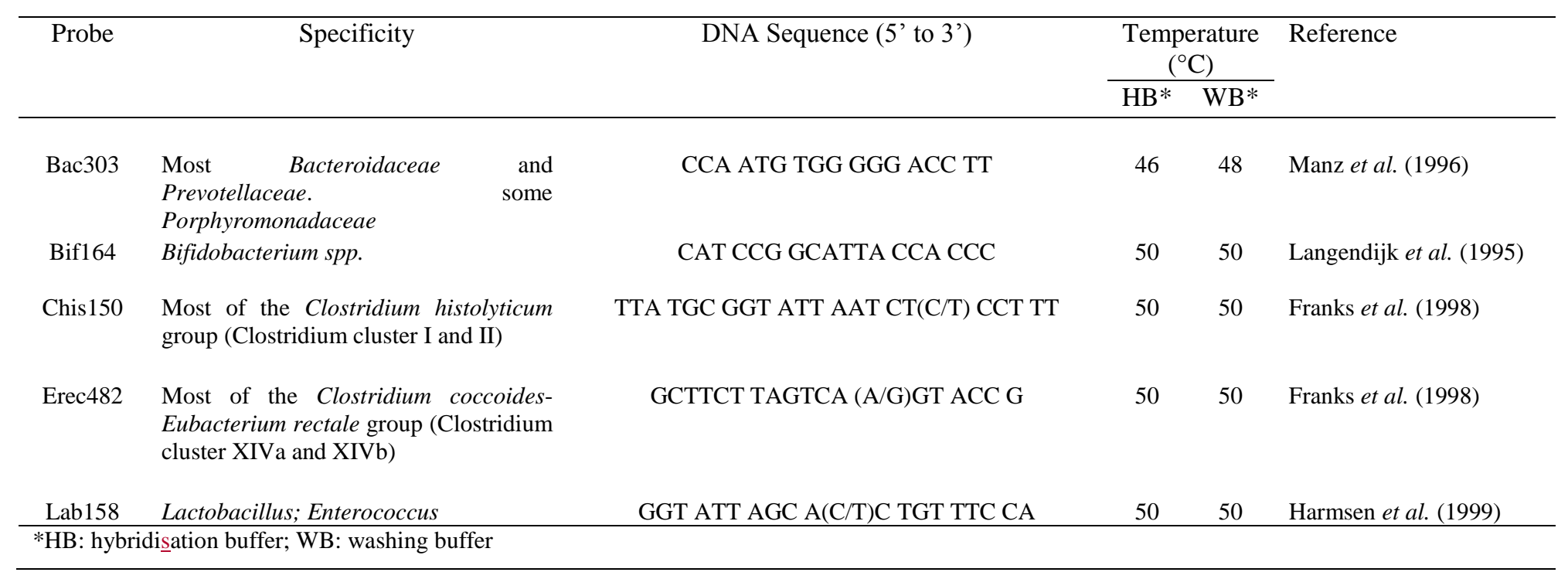




\section{Results and discussion}

The yields of extraction of pectin from artichoke (22.1\%) and sunflower byproducts $(10.0 \%)$ were in line with those obtained for other well-established sources of pectin, such as citrus peel (Kurita, Fujiwara, \& Yamazaki, 2008), lime peel (Dominiak et al., 2014), apple pomace (Wikiera, Mika, Starzyńska-Janiszewska, \& Stodolak, 2015) or passion fruit peels (Liew, Chin, Yusof, \& Sowndhararajan, 2016), suggesting their potential use as renewable pectin sources.

\subsection{Characterisation of pectin and enzymatic-modified pectin samples}

Pectins from different sources (that is, citrus, artichoke and sunflower) and their enzymatic modified polysaccharides (modified pectin (MP)) were evaluated in this study. Neutral sugars and GalA content, average degree of methylation and average estimated Mw are included in Table 2. The GalA:Rha ratio displayed in the table shows the number of GalA residues per Rha residue, giving an indication of the RG-I backbone respect to HG content. Thus, a lower value shows a compound richer in RG-I chains. Ara:Rha and Gal:Rha ratios indicate the number of neutral sugar residues attached to the RG-I backbone.

As expected, GalA was the major monosaccharide residue in all pectic samples, ranging from $46.5 \%(\mathrm{w} / \mathrm{w})$ to $88.1 \%(\mathrm{w} / \mathrm{w})$. The lowest values of GalA content were observed in those samples which had the highest values of rhamnose content. In consequence, the GalA:Rha ratio indicated that citrus MP, artichoke pectin, artichoke MP and citrus pectin were the most enriched samples in RG-I as compared to sunflower samples, which were the most enriched in HG structure according to the monomeric composition (27.4 and 24.1 for GalA:Rha ratio for sunflower pectin and sunflower MP, respectively). Instead, artichoke pectin and MP presented high amounts of arabinose, surpassing rhamnose content, which could be indicative of a highly enriched structure in 


\section{Table 2}

Chemical characterisation of pectins and enzymatic-modified pectins from different renewable bioresources.

\begin{tabular}{|c|c|c|c|c|c|c|c|c|c|c|c|c|}
\hline \multirow[b]{2}{*}{ Sample } & \multicolumn{11}{|c|}{ Monosaccharide (\%*) } & \multirow[b]{2}{*}{$\begin{array}{c}\text { Average } \\
\text { degree of } \\
\text { methylation } \\
(\%) \\
\end{array}$} \\
\hline & Xylose & Arabinose & Rhamnose & Galactose & Mannose & Glucose & $\begin{array}{c}\text { Galacturonic } \\
\text { acid }\end{array}$ & \begin{tabular}{|c|} 
Average \\
$\mathbf{M w}$ \\
$(\mathbf{k D a})$ \\
\end{tabular} & GalA:Rha & Ara:Rha & Gal:Rha & \\
\hline Citrus Pectin & $0.9 \pm 0.0$ & $3.5 \pm 0.0$ & $5.8 \pm 0.0$ & $20.2 \pm 0.1$ & $1.4 \pm 0.0$ & $1.8 \pm 0.0$ & $66.5 \pm 0.2$ & $800-100$ & 11.52 & 0.61 & 3.50 & 70.7 \\
\hline Citrus MP & $1.3 \pm 0.2$ & $3.7 \pm 0.2$ & $9.8 \pm 0.1$ & $14.0 \pm 0.3$ & $2.4 \pm 0.3$ & $13.3 \pm 0.3$ & $55.6 \pm 0.6$ & $12.0-10.0$ & 5.70 & 0.38 & 1.44 & 14.2 \\
\hline Sunflower Pectin & $2.2 \pm 0.1$ & $1.1 \pm 0.0$ & $3.2 \pm 0.4$ & $4.3 \pm 0.0$ & $0.1 \pm 0.0$ & $0.9 \pm 0.0$ & $88.1 \pm 0.9$ & $800-100$ & 27.39 & 0.35 & 1.35 & 45.7 \\
\hline Sunflower MP & $0.9 \pm 0.0$ & $2.3 \pm 0.0$ & $3.2 \pm 0.1$ & $12.2 \pm 0.0$ & $1.3 \pm 0.0$ & $1.8 \pm 0.0$ & $78.2 \pm 0.5$ & 12.5 & 24.13 & 0.71 & 3.77 & 17.0 \\
\hline Artichoke Pectin & $1.1 \pm 0.1$ & $18.9 \pm 0.6$ & $7.6 \pm 0.1$ & $8.2 \pm 0.3$ & $1.0 \pm 0.3$ & $16.7 \pm 0.7$ & $46.5 \pm 0.6$ & $>500$ & 6.13 & 2.50 & 1.09 & 8.9 \\
\hline Artichoke MP & $2.3 \pm 0.2$ & $10.7 \pm 0.1$ & $5.4 \pm 0.0$ & $21.1 \pm 0.0$ & $1.2 \pm 0.0$ & $3.9 \pm 0.0$ & $55.5 \pm 0.8$ & $300-80$ & 10.34 & 1.99 & 3.94 & 8.5 \\
\hline
\end{tabular}

Analysis were carried out at least in duplicate $(\mathrm{n}=2)$

*Monosaccharide content $(\%)$ is referred regarding the total carbohydrate measured on each sample. 
arabinan and arabinogalactan branches to the RG-I chains. The amount of rhamnose and arabinose with respect to GalA may also indicate the substitution of the rhamnogalacturonan branching along the $\mathrm{HG}$ with arabinan and arabinogalactan structures (Manderson et al., 2005; Yuliarti, Goh, Matia-Merino, Mawson, \& Brennan, 2015). The high content of arabinose and GalA determined in artichoke samples support the data obtained in previous studies (Femenia, Robertson, Waldron, \& Selvendran, 1998; Sabater et al., 2018). Galactose content in all samples was higher than other neutral sugars, with the exception of arabinose in artichoke pectin, which may also indicate the presence of galactose-based oligosaccharides branched to the HG backbone. Xylose that can be present in more complex structural features of pectin, such as RG-II regions or arabinoxylans and xylogalacturonan (Maxwell et al., 2012), ranged from $0.9 \%$ to $2.3 \%$. Lastly, glucose (from $0.9 \%$ to $16.7 \%$ ) and mannose (from $0.1 \%$ to $2.4 \%$ ) were found in all samples and they could likely derive from non-pectic polysaccharides extracted in minor amounts together the target pectins, such as xyloglucan, hemicellulose, and/or cellulose (Yapo, 2009; Wang et al., 2016; Sabater et al., 2018).

In both artichoke samples the degree of methylation was the lowest ( 8.9 and $8.5 \%$ for pectin and MP, respectively), whereas MP samples from citrus and sunflower had moderately higher values (14.2 and $17.0 \%$, respectively) and citrus and sunflower pectin had the highest data of all samples with $70.7 \%$ and $45.7 \%$ of degree of methylation, respectively. This behaviour could be ascribed to the pectin methyl esterase activity of the enzyme employed to produce the corresponding MP.

On the other hand, all resulting MP showed a reduction of the Mw as compared to their respective pectin due to the polygalacturonase enzyme activity, which was concomitant with a decrease in GalA and an increase in RG-I to HG. However, modified artichoke pectin showed a decrease in arabinose which led to a higher relative 
333 content of GalA compared to its parent pectin. The initial high content of arabinose

334 observed in artichoke pectin could be related to the resulting high Mw of artichoke MP

335 following enzymatic treatment. It is well known that arabinose is present in pectin as

336 arabinan side chains and, consequently, a high degree of branching may create steric

337 hindrance impairing the efficient cutting of the main chain composed by GalA. The

338 decrease in $\mathrm{Mw}$ was correlated to the diminution of degree of methylation observed in

339 citrus and sunflower samples. It is interesting to note that citrus and sunflower MP

340 exhibited a Mw of $10-12.5 \mathrm{kDa}$ which is in line with other modified pectins obtained

341 from citrus $(-10 \mathrm{kDa})$ that have shown to be effective supplements in the treatment of

342 cancer and other diseases (Morris et al., 2013). Artichoke MP showed a small decrease

343 in this parameter which is in accordance with its high Mw, as shown in Figure 1. 

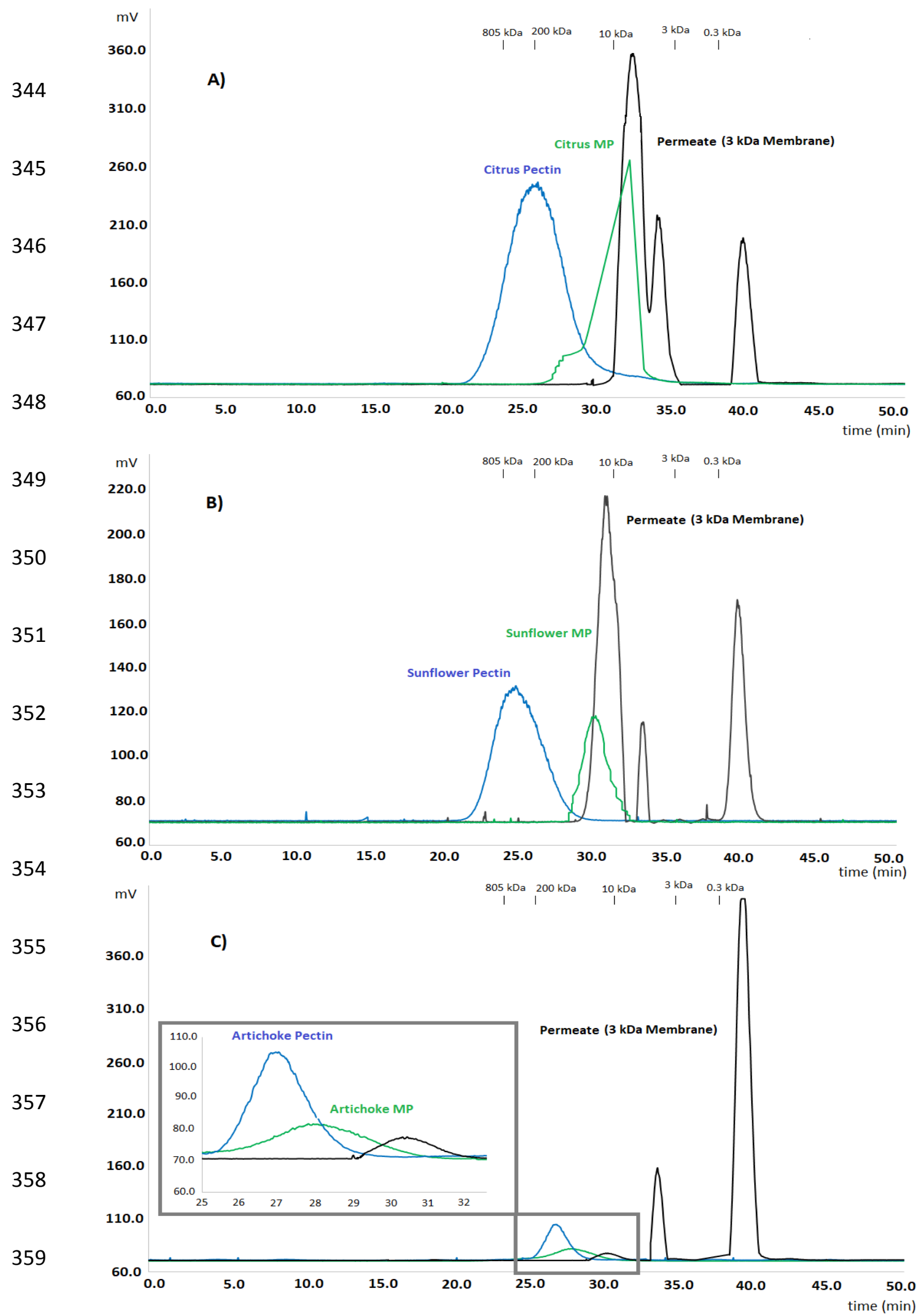

360 Figure 1. SEC-ELSD profiles of pectins (blue), enzymatic-modified pectins (MP)

361 (green), and corresponding ultrafiltrated permeates (black) derived from A) citrus, B)

362 sunflower, and C) artichoke sources. Elution positions of standard polysaccharide

363 polymers (pullulans) are indicated by arrows. 
366 Changes in the human faecal bacterial populations during the in vitro fermentation 367 with the different pectins and enzymatic-modified pectins after $24 \mathrm{~h}$ are shown in Table 368 3. A significant increase $(p<0.05)$ of Bifidobacterium (Bif164) population for all 369 carbohydrate samples was observed after $24 \mathrm{~h}$ of fermentation. It is well known that 370 oligosaccharides deriving from pectins have bifidogenic activities, however there are 371 also studies that have demonstrated a bifidogenic effect in intact pectins suggesting a 372 potential role of this polysaccharide as a prebiotic (Gómez et al., 2016; Yang, Martínez, 373 Walter, Keshavarzian, \& Rose, 2013). In our study, numerical increases up to 0.79 $3741.19 \log _{10}$ in population were determined. Some authors indicated that increments of 0.5 $375-1.0 \log _{10}$ in bifidobacteria could be considered as a major shift in the gut microbiota 


\section{Table 3}

Bacterial populations ( $\log 10$ cells per ml) enumerated by FISH at 0 and $24 \mathrm{~h}$ of in vitro fermentation with Inulin, FOS, citrus pectin, citrus modified pectin (MP), sunflower pectin, sunflower MP, artichoke pectin and artichoke MP.

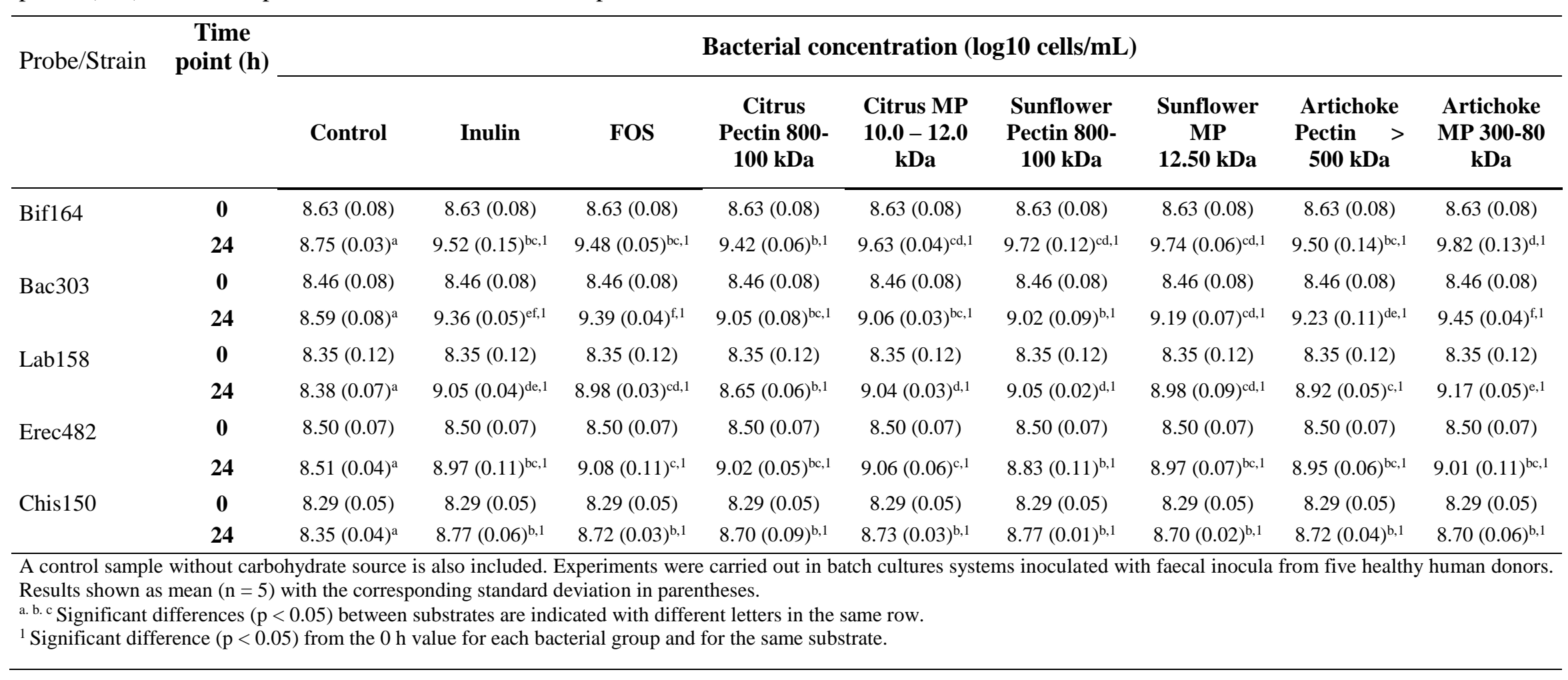


towards a potentially healthier composition of intestinal microbiota (Kolida \& Gibson, 2007). Thus, all pectic samples could be considered bifidogenic under the studied conditions. Remarkably, artichoke MP was the substrate, which promoted the significantly highest growth in bifidobacteria among all assayed samples, including positive controls as inulin and FOS which in turn showed a similar bifidobacterial growth as compared to sunflower and citrus samples. This fact could be attributed to the high combined content of arabinose and galactose found in artichoke MP (Table 2) according to previous studies reporting a correlation between arabinose and galactose content with bifidogenic properties (Di et al., 2017; Manderson et al., 2005; Onumpai et al., 2011). Moreover, a positive effect of the decrease of $\mathrm{Mw}$ in pectin on its ability to promote bifidobacteria growth was observed for citrus and artichoke sources since their MP derivatives exhibited a significant $(p<0.05)$ increase as compared to unmodified pectin (9.63 vs $9.42 \log _{10}$ for citrus and 9.82 vs. 9.50 for artichoke), whereas sunflower pectin and MP presented a statistically identical bifidogenic activity. Evidently, there was not any significant increase during fermentation of negative controls, confirming the suitability of these substrates as a carbon source for the metabolism of bifidobacteria. The degree of methylation did not have impact on the bifidogenic properties. More specifically, sunflower samples had different value of this parameter with the same bifidogenic activity and artichoke samples had almost the same one with different bifidogenic activity.

The second highest increase (up to $0.56-0.93 \log _{10}$ ) was observed in Bacteroides/Prevotella (Bac303) population. This general increase is explained by the fact that Bacteroides species are major carbohydrate-degrading organisms in the gut and have the capacity to degrade diverse plant polysaccharides, including pectins (Dongowski, Lorenz, \& Anger, 2000; Flint, Scott, Duncan, Louis, \& Forano, 2012; 
401 Onumpai et al., 2011). Indeed, many Bacteroides strains from human faeces can

402

403

404

405

406

407

408

409

410

411

412 produce pectinolytic enzymes, including polygalacturonase and pectin methylesterase (Dekker \& Palmer, 1981; Jensen \& Canale-parola, 1986). Therefore, Bacteroides can be involved in cross-feeding with Bifidobacteria by releasing breakdown products of pectin or MP which might be utilised by the latter, thus, promoting their growth. Inulin, FOS and artichoke MP samples exhibited the highest increase in Bacteroides. With respect to the effect of $\mathrm{Mw}$ on Bacteroides/Prevotella growth, sunflower and artichoke MP demonstrated a significantly higher increase than their respective pectins. This difference could be attributed to the galactan chains branched to the RG-I since Gal:Rha ratio increased in both sunflower and artichoke MP after the enzymatic hydrolysis.

A significant increase in Lactobacillus/Enterococcus (Lab158) was also observed for all tested carbohydrate samples, with the most significant increases found in inulin and artichoke MP. Similar to Bifidobacterium, Lactobacillus is considered one of the major microbial targets for prebiotic action due to their health effects. The high increment in Lactobacillus/Enterococcus population following artichoke MP fermentation further established the correlation of arabinose and galactose content with the prebiotic properties. Mw did not affect sunflower samples but it seemed to have an impact on citrus and artichoke sources, in a similar manner to the behaviour observed for Bifidobacterium selectivity.

Clostridium coccoides/Eubacterium rectale (Erec482) showed a significant increase in all tested samples but no significant differences were found among any of the carbohydrate substrates including inulin and FOS. Increase in Eubacterium rectale is of particular interest due to its ability to produce butyrate (Manderson et al., 2005). Di et al. (2017) reported an increase of Erec482 numbers when testing a citrus MP of similar Mw $(9.2 \mathrm{kDa})$, although they did not find a positive correlation with the determined 
butyrate concentrations. In the same way, Chen et al. (2013) reported enhanced

427 Eubacteria growth on apple pectin compared to the respective POS, suggesting that the Mw was not a relevant factor. In our work, similar behaviour was observed since all pectic samples resulted in a significant stimulation of the butyrate producing bacteria groups (Erec482) and no differences were found between samples with different Mw or origin.

Clostridium histolyticum (Chis150) population displayed the lowest changes in all cases, leading to a rather moderate increase (lower than $0.5 \log _{10}$ ) after $24 \mathrm{~h}$ of fermentation. No significant differences among any substrates were observed after fermentation. In general, Clostridium species are considered as potentially harmful bacteria, so in this way, all pectic samples induced a favourable behaviour.

Acetate, propionate, butyrate and total SCFA formation was analysed throughout the fermentation in batch cultures (Table 4). Total SCFA concentration increased strongly during the first 10 or $24 \mathrm{~h}$ of fermentation in all tested substrates. In general terms, neither the degree of methylation nor Mw of pectin samples had an influence on the SCFA production, as reflected by the values contained in Table 4.

Acetate was the most abundant SCFA, followed by propionic and butyric acids in all substrates. Formation of acetate has been related to an enhancement of the ileal motility, a protection against genotoxic agents and pathogens and an increase of colonic blood (Hong et al., 2005). In our study, the only significant differences found between samples after $48 \mathrm{~h}$ of analysis were with artichoke and citrus MPs. Results demonstrated 
Table 4

SCFA concentrations (mM) determined by GC-FID at $0,10,24,36$ and $48 \mathrm{~h}$ on in vitro fermentations with Inulin, FOS, citrus pectin, citrus modified pectin (MP), sunflower pectin, sunflower MP, artichoke pectin and artichoke MP.

\begin{tabular}{|c|c|c|c|c|c|c|c|c|c|c|}
\hline \multirow{2}{*}{ SCFA } & \multirow{2}{*}{$\begin{array}{c}\text { Time } \\
\text { point }(h)\end{array}$} & \multicolumn{9}{|c|}{ Mean SCFA concentration $(\mathrm{mM})$ in substrate } \\
\hline & & Control & Inulin & FOS & $\begin{array}{l}\text { Citrus Pectin } \\
\text { 800-100 kDa }\end{array}$ & $\begin{array}{l}\text { Citrus MP } \\
10.0-12.0 \\
\text { kDa }\end{array}$ & $\begin{array}{c}\text { Sunflower } \\
\text { Pectin 800-100 } \\
\text { kDa }\end{array}$ & $\begin{array}{c}\text { Sunflower MP } \\
12.50 \mathrm{kDa}\end{array}$ & $\begin{array}{l}\text { Artichoke } \\
\text { Pectin > } \\
500 \text { kDa }\end{array}$ & $\begin{array}{c}\text { Artichoke MP } \\
300-80 \text { kDa }\end{array}$ \\
\hline \multirow[t]{5}{*}{ Acetate } & $\mathbf{0}$ & $3.80(1.55)$ & $3.80(1.55)$ & $3.80(1.55)$ & $3.80(1.55)$ & $3.80(1.55)$ & $3.80(1.55)$ & $3.80(1.55)$ & $3.80(1.55)$ & $3.80(1.55)$ \\
\hline & 10 & $12.28(3.30)^{\mathrm{a}, 1}$ & $36.99(6.60)^{\mathrm{b}, 1}$ & $54.64(15.10)^{\mathrm{bcd}, 1}$ & $61.65(11.81)^{\mathrm{cd}, 1}$ & $68.49(6.19)^{\mathrm{d}, 1}$ & $50.64(9.15)^{\mathrm{bcd}, 1}$ & $58.47(4.13)^{\mathrm{cd}, 1}$ & $49.35(5.54)^{\mathrm{bcd}, 1}$ & $42.19(3.77)^{\mathrm{bc}, 1}$ \\
\hline & 24 & $21.11(3.31)^{\mathrm{a}, 2}$ & $62.44(11.68)^{\mathrm{bcd}, 2}$ & $57.89(14.88)^{\mathrm{bc}}$ & $78.42(9.02)^{\mathrm{cd}}$ & $78.83(12.87)^{\mathrm{cd}}$ & $82.65(11.80)^{\mathrm{d}, 2}$ & $69.21(10.29)^{\mathrm{bcd}}$ & $55.33(1.62)^{\mathrm{b}}$ & $50.86(7.81)^{\mathrm{b}}$ \\
\hline & 36 & $26.18(4.49)^{\mathrm{a}}$ & $65.24(11.98)^{\mathrm{bc}}$ & $63.68(10.80)^{\mathrm{bc}}$ & $71.18(11.38)^{\mathrm{bc}}$ & $78.95(11.71)^{\mathrm{c}}$ & $78.95(11.62)^{\mathrm{c}}$ & $67.64(9.27)^{\mathrm{bc}}$ & $55.64(4.57)^{\mathrm{b}}$ & $55.60(11.09)^{\mathrm{b}}$ \\
\hline & 48 & $17.62(3.38)^{\mathrm{a}}$ & $64.42(10.55)^{\mathrm{bc}}$ & $63.55(10.86)^{\mathrm{bc}}$ & $77.99(14.69)^{\mathrm{bc}}$ & $85.40(11.34)^{\mathrm{c}}$ & $78.49(13.31)^{\mathrm{bc}}$ & $73.87(10.49)^{\mathrm{bc}}$ & $61.00(12.27)^{\mathrm{bc}}$ & $55.94(8.95)^{\mathrm{b}}$ \\
\hline \multirow[t]{5}{*}{ Propionate } & $\mathbf{0}$ & $0.54(0.27)$ & $0.54(0.27)$ & $0.54(0.27)$ & $0.54(0.27)$ & $0.54(0.27)$ & $0.54(0.27)$ & $0.54(0.27)$ & $0.54(0.27)$ & $0.54(0.27)$ \\
\hline & 10 & $2.28(0.92)^{\mathrm{a}}$ & $7.58(1.91)^{\mathrm{ab}}$ & $12.20(6.90)^{\mathrm{b}}$ & $8.13(3.22)^{\mathrm{ab}, 1}$ & $11.6(3.76)^{\mathrm{b}, 1}$ & $6.35(2.33)^{\mathrm{ab}, 1}$ & $10.00(1.10)^{\mathrm{ab}, 1}$ & $11.35(4.10)^{\mathrm{b}, 1}$ & $11.27(3.17)^{\mathrm{b}, 1}$ \\
\hline & 24 & $4.7(1.26)^{\mathrm{a}, 2}$ & $18.17(4.69)^{\mathrm{b}, 2}$ & $15.64(6.76)^{\mathrm{b}, 1}$ & $12.12(4.58)^{\mathrm{ab}}$ & $16.04(1.86)^{b}$ & $11.82(1.26)^{\mathrm{ab}, 2}$ & $13.84(0.90)^{\mathrm{b}, 2}$ & $13.49(3.98)^{\mathrm{b}}$ & $15.69(1.37)^{\mathrm{b}, 2}$ \\
\hline & 36 & $4.1(0.60)^{\mathrm{a}}$ & $19.51(5.68)^{\mathrm{cd}}$ & $23.77(2.89)^{\mathrm{d}}$ & $11.92(4.26)^{\mathrm{b}}$ & $16.15(2.26)^{\mathrm{bcd}}$ & $11.80(1.47)^{\mathrm{b}}$ & $14.12(1.61)^{\mathrm{bc}}$ & $14.55(3.51)^{\mathrm{bc}}$ & $16.97(1.62)^{\mathrm{bcd}}$ \\
\hline & 48 & $2.12(0.99)^{\mathrm{a}}$ & $18.41(4.95)^{\mathrm{bc}}$ & $20.69(6.22)^{\mathrm{c}}$ & $12.71(3.51)^{\mathrm{b}}$ & $17.35(2.12)^{\mathrm{bc}, 2}$ & $13.60(3.01)^{\mathrm{bc}}$ & $14.15(1.82)^{\mathrm{bc}}$ & $14.10(3.61)^{\mathrm{bc}}$ & $16.10(2.03)^{\mathrm{bc}}$ \\
\hline \multirow[t]{5}{*}{ Butyrate } & $\mathbf{0}$ & $0.96(0.17)$ & $0.96(0.17)$ & $0.96(0.17)$ & $0.96(0.17)$ & $0.96(0.17)$ & $0.96(0.17)$ & $0.96(0.17)$ & $0.96(0.17)$ & $0.96(0.17)$ \\
\hline & 10 & $1.29(0.64)^{\mathrm{a}}$ & $6.57(0.75)^{b}$ & $3.43(2.17)^{\mathrm{ab}}$ & $1.82(1.94)^{\mathrm{a}}$ & $2.51(1.36)^{\mathrm{a}}$ & $2.22(1.10)^{\mathrm{a}}$ & $3.26(1.52)^{\mathrm{ab}}$ & $2.70(1.88)^{\mathrm{a}}$ & $2.74(1.12)^{\mathrm{a}}$ \\
\hline & 24 & $1.77(1.03)^{\mathrm{a}}$ & $9.13(2.22)^{b, 1}$ & $5.20(3.28)^{\mathrm{ab}}$ & $4.52(1.94)^{\mathrm{a}, 1}$ & $4.94(1.54)^{\mathrm{ab}, 1}$ & $4.54(2.19)^{\mathrm{a}, 1}$ & $5.42(1.59)^{\mathrm{ab}, 1}$ & $5.30(1.68)^{\mathrm{ab}, 1}$ & $4.50(0.78)^{\mathrm{a}, 1}$ \\
\hline & 36 & $2.31(0.67)^{\mathrm{a}, 1}$ & $9.66(3.14)^{\mathrm{c}}$ & $7.60(3.20)^{\mathrm{bc}, 1}$ & $5.86(2.26)^{\mathrm{abc}, 2}$ & $5.35(1.87)^{\mathrm{abc}, 2}$ & $5.13(1.88)^{\mathrm{abc}}$ & $6.23(1.80)^{\mathrm{abc}}$ & $5.25(2.22)^{\mathrm{abc}}$ & $4.98(1.34)^{\mathrm{ab}}$ \\
\hline & 48 & $1.06(0.38)^{\mathrm{a}}$ & $9.08(2.87)^{\mathrm{b}}$ & $8.40(3.85)^{b}$ & $4.92(2.08)^{\mathrm{ab}}$ & $5.89(1.59)^{\mathrm{ab}}$ & $4.78(1.31)^{\mathrm{ab}}$ & $6.33(2.61)^{b}$ & $6.04(3.04)^{b}$ & $4.98(1.87)^{\mathrm{ab}}$ \\
\hline \multirow[t]{5}{*}{ Total } & $\mathbf{0}$ & $5.26(1.90)$ & $5.26(1.90)$ & $5.26(1.90)$ & $5.26(1.90)$ & $5.26(1.90)$ & $5.26(1.90)$ & $5.26(1.90)$ & $5.26(1.90)$ & $5.26(1.90)$ \\
\hline & 10 & $15.84(4.61)^{\mathrm{a}, 1}$ & $49.14(13.14)^{\mathrm{b}, 1}$ & $83.76(17.01)^{\mathrm{c}, 1}$ & $71.42(12.18)^{\mathrm{bc}, 1}$ & $82.95(6.94)^{\mathrm{c}, 1}$ & $59.21(11.65)^{\mathrm{bc}, 1}$ & $71.74(6.46)^{\mathrm{bc}, 1}$ & $63.89(10.69)^{\mathrm{bc}, 1}$ & $56.20(7.58)^{\mathrm{b}, 1}$ \\
\hline & 24 & $27.83(3.69)^{\mathrm{a}, 2}$ & $90.30(11.28)^{\mathrm{bcd}, 2}$ & $84.14(17.36)^{\mathrm{bcd}}$ & $94.15(11.21)^{\mathrm{bcd}}$ & $102.36(14.94)^{\mathrm{d}}$ & $99.01(11.79)^{\mathrm{cd}, 2}$ & $89.70(9.42)^{\mathrm{bcd}}$ & $74.99(3.97)^{\mathrm{bc}}$ & $72.42(9.24)^{\mathrm{b}}$ \\
\hline & 36 & $32.24(4.55)^{\mathrm{a}}$ & $95.90(13.77)^{\mathrm{b}}$ & $90.74(15.10)^{\mathrm{b}}$ & $88.97(14.71)^{b}$ & $97.03(18.08)^{\mathrm{b}}$ & $95.88(12.16)^{\mathrm{b}}$ & $89.64(10.97)^{b}$ & $77.27(8.63)^{\mathrm{b}}$ & $79.42(13.64)^{\mathrm{b}, 2}$ \\
\hline & 48 & $21.21(3.96)^{\mathrm{a}}$ & $90.38(18.27)^{\mathrm{bc}}$ & $91.45(11.89)^{\mathrm{bc}}$ & $95.63(16.72)^{\mathrm{bc}}$ & $109.42(12.10)^{\mathrm{c}}$ & $96.87(13.57)^{\mathrm{bc}}$ & $98.84(9.49)^{\mathrm{bc}, 2}$ & $83.19(17.16)^{\mathrm{bc}}$ & $77.02(11.35)^{b}$ \\
\hline \multicolumn{11}{|c|}{ 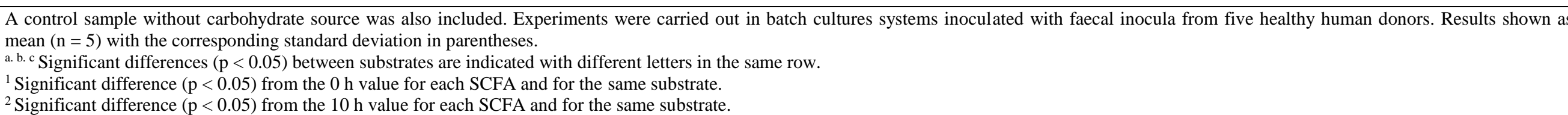 } \\
\hline
\end{tabular}


challenging to attribute a particular fermentation end-product to a specific bacterial group in a mixed culture system, overall the increase in acetate is in agreement with the dynamics of the microbial populations, since all samples promoted the growth of Bifidobacterium and Lactobacillus (Table 3), which are acetate producers. Additionally, these end-products may serve as substrates for other bacteria due to metabolic cross-feeding (Belenguer et al., 2006). Acetate is generated by many bacterial groups that inhabit the colon, with approximately one-third of the product coming from reductive acetogenesis (Miller \& Wolin, 1996). In contrast, bacterial groups that form propionate and butyrate are specialised and are of particular interest in terms of their beneficial effects. The main propionate-producing bacteria in the human colon are Bacteroides and Clostridium whereas butyrate production is related to bacterial groups such as Clostridium histolyticum (clusters I, II, IV, XIVa, XV and XVI) and Eubacterium rectale.

An increase in propionate concentration was seen in all samples after $48 \mathrm{~h}$ of fermentation, whereas fermentation of inulin and FOS resulted in the highest increase among all samples. Similarly to acetate, the high variability found among the five donors meant that propionate differences between all samples were not considered statistically significant $(p>0.05)$ during the first $24 \mathrm{~h}$ of fermentation. However, the increase in this end-product is in good agreement with the increase in Bacteroides population displayed in Table 3. Propionate has also been shown to exert beneficial effects on host health, such as reduction of food intake and enhancement of satiety via augmentation of the satiety hormone leptin (Zeng, 2014), and a protective role against

472 carcinogenesis through the decrease in human colon cancer cell growth via 473 hyperacetylation of histone proteins and stimulation of apoptosis (Hinnebusch, Meng, 474 Wu, Archer, \& Hodin, 2002; Jan et al., 2002). 

fermentation. FOS and inulin showed the highest increase after $48 \mathrm{~h}$ of fermentation,

477 although non-significant differences were observed among all substrates due to the high inter-individual variability (Table 4). The low but significant increase in butyrate levels are in accordance with the increase of Erec482 and Chis 150 numbers which also include some of the major butyrate-produces (Eubacterium rectale and Clostridium histolyticum). Although acetate, propionate and butyrate are all metabolised to some extent by the epithelium to provide energy, butyrate plays a critical role in maintaining colonic health and moderating cell growth (Zeng, 2014). Compared to acetate and propionate, butyrate exhibits strong anti-inflammatory properties, likely mediated by inhibition of TNF- $\alpha$ production, NF- $\kappa \mathrm{B}$ activation, and IL-8, -10, -12 expression in immune and colonic epithelial cells and a protective role against colon cancer (Bailón et al., 2010; Zeng, 2014).

\section{Conclusions}

Findings in this work highlight the suitability of artichoke and sunflower byproducts as renewable sources of bioactive pectic compounds since the reported yields were within the range observed for other well-established pectin sources. To the best of our knowledge, this is the first evidence of prebiotic potential of pectic compounds from sunflower and artichoke and also supports the important role played by the arabinoserich rhamnogalacturonic acids in stimulating Bifidobacteria. A positive effect of decreasing molecular weight on fermentation properties was found in artichoke and citrus sources since their respective enzymatically-modified pectins promoted significantly higher growth in Bifidobacterium and Lactobacillus than the corresponding unmodified pectin. In the case of sunflower, this behaviour was only 
500 observed in Bacteroides/Prevotella, which also grew to significantly higher population

501 levels on artichoke MP as compared to the unmodified pectin. No significant effects of 502 the molecular weight of pectin samples on SCFA production were observed, although

503 this could be due to the high inter-individual variability observed in acetate, propionate 504 and butyrate formation. Likewise, the degree of methylation did not have any 505 significant impact on the fermentability nor SCFA production, regardless the origin of 506 the pectic compounds.

507 To conclude, although further in vivo studies should be conducted, our data reveal 508 that either pectin or enzymatically-modified pectin from sunflower and artichoke by509 products might be considered as efficient prebiotic candidates for human consumption 510 showing similar ability to promote the in vitro growth of beneficial gut bacteria as 511 Bifidobacterium and Lactobacillus in comparison to well-recognized prebiotics as inulin 512 and FOS.

\section{Acknowledgements}

This work has been funded by MINECO of Spain, Project AGL2014-53445- R.

516 The authors thank Syngenta and Riberebro for supplying the sunflower heads and 517 artichoke by-products, respectively. 
521

522

523

524

525

526

527

528

529

530

531

532

533

534

535

536

537

538

539

540

541

542

543

544

Bailón, E., Cueto-Sola, M., Utrilla, P., Rodríguez-Cabezas, M. E., Garrido-Mesa, N., Zarzuelo, A., Xaus J., Gálvez, J. \& Comalada, M. (2010). Butyrate in vitro immune-modulatory effects might be mediated through a proliferation-related induction of apoptosis. Immunobiology, 215(11), 863-873.

Belenguer, A., Duncan, S. H., Calder, a G., Holtrop, G., Louis, P., Lobley, G. E., \& Flint, H. J. (2006). Two Routes of Metabolic Cross-Feeding between Bifidobacterium adolescentis and Butyrate-Producing Anaerobes from the Human Gut. Applied and Environmental Microbiology, 72(5), 3593-3599.

Cardelle-Cobas, A., Martínez-Villaluenga, C., Sanz, M. L., \& Montilla, A. (2009). Gas chromatographic-mass spectrometric analysis of galactosyl derivatives obtained by the action of two different $\beta$-galactosidases. Food Chemistry, 114(3), 1099-1105.

Chen, J., Liang, R. H., Liu, W., Li, T., Liu, C. M., Wu, S. S., \& Wang, Z. J. (2013). Pecticoligosaccharides prepared by dynamic high-pressure microfluidization and their in vitro fermentation properties. Carbohydrate Polymers, 91(1), 175-182.

Costabile, A., Kolida, S., Klinder, A., Gietl, E., Bäuerlein, M., Frohberg, C., Landschütze, V., \& Gibson, G. R. (2010). A double-blind, placebo-controlled, cross-over study to establish the bifidogenic effect of a very-long-chain inulin extracted from globe artichoke (Cynara scolymus) in healthy human subjects. British Journal of Nutrition, 104, 1007-1017.

Dekker, J., \& Palmer, J. K. (1981). Enzymatic degradation of the plant cell wall by a Bacteroides of human fecal origin. Journal of Agricultural and Food Chemistry, 29(3), $480-484$.

Di, R., Vakkalanka, M. S., Onumpai, C., Chau, H. K., White, A., Rastall, R. A., Yam K. \& Hotchkiss, A. T. (2017). Pectic oligosaccharide structure-function relationships: Prebiotics, inhibitors of Escherichia coli O157:H7 adhesion and reduction of Shiga toxin 
546

Dominiak, M., Søndergaard, K. M., Wichmann, J., Vidal-Melgosa, S., Willats, W. G. T., Meyer, A. S., \& Mikkelsen, J. D. (2014). Application of enzymes for efficient extraction, modification, and development of functional properties of lime pectin. Food Hydrocolloids, 40, 273-282.

Dongowski, G., Lorenz, A., \& Anger, H. (2000). Degradation of Pectins with Different Degrees of Esterification by Bacteroides thetaiotaomicron Isolated from Human Gut Flora Degradation of Pectins with Different Degrees of Esterification by Bacteroides thetaiotaomicron Isolated from Human Gut Flora. Applied and Environmental Microbiology, 66(4), 1321-1327.

Fanaro, S., Jelinek, J., Stahl, B., Boehm, G., Kock, R., \& Vigi, V. (2005). Acidic oligosaccharides from pectin hydrolysate as new component for infant formulae: effect on intestinal flora, stool characteristics, and pH. Journal of Pediatric Gastroenterology and Nutrition, 41, 186-190,

Femenia, A., Robertson, J. A., Waldron, K. W., \& Selvendran, R. R. (1998). Cauliflower (Brassica oleracea L), globe artichoke (Cynara scolymus) and chicory witloof (Cichorium intybus) processing by-products as sources of dietary fibre. Journal of the Science of Food and Agriculture, 77, 511-518.

Fissore, E. N., Santo Domingo, C., Gerschenson, L. N., \& Giannuzzi, L. (2015). A study of the effect of dietary fiber fractions obtained from artichoke (Cynara cardunculus L. var. scolymus) on the growth of intestinal bacteria associated with health. Food and Function, $6,1667-1674$.

Flint, H. J., Scott, K. P., Duncan, S. H., Louis, P., \& Forano, E. (2012). Microbial degradation of complex carbohydrates in the gut. Gut Microbes, 3(4), 289-306.

569 Franks, A. H., Harmsen, H. J. M., Raangs, G. C., Jansen, G. J., Schut, F., \& Welling, G.W. 

(1998). Variations of bacterial populations in human feces measured by fluorescent in situ hybridization with group-specific 16S rRNA-targeted oligonucleotide probes. Applied and Environmental Microbiology, 64, 3336-3345.

Gómez, B., Gullón, B., Yáñez, R., Schols, H., \& Alonso, J. L. (2016). Prebiotic potential of pectins and pectic oligosaccharides derived from lemon peel wastes and sugar beet pulp: A comparative evaluation. Journal of Functional Foods, 20, 108-121.

Gullón, B., Gómez, B., Martínez-Sabajanes, M., Yáñez, R., Parajó, J. C., \& Alonso, J. L. (2013). Pectic oligosaccharides: Manufacture and functional properties. Trends in Food Science and Technology, 30(2), 153-161.

Harmsen, H. J. M., Elfferich, P., Schut, F., \& Welling, G.W. (1999). A 16S rRNA-targeted probe for detection of Lactobacilli and Enterococci in faecal samples by fluorescent in situ hybridization. Microbial Ecology in Health and Disease, 11, 3-12.

Hinnebusch, B. F., Meng, S., Wu, J. T., Archer, S. Y., \& Hodin, R. A. (2002). The effects of short-chain fatty acids on human colon cancer cell phenotype are associated with histone hyperacetylation. The Journal of Nutrition, 132(5), 1012-1017.

Holck, J., Hotchkiss, A. T., Meyer, A. S., Mikkelsen, J. D., \& Rastall, R. A. (2014). Production and Bioactivity of Pectic Oligosaccharides from Fruit and Vegetable Biomass. In F. J. Moreno, \& M. L. Sanz (Eds.), Food Oligosaccharides: Production, Analysis and Bioactivity (pp. 76-87). UK, John Wiley \& Sons.

Hong, Y. H., Nishimura, Y., Hishikawa, D., Tsuzuki, H., Miyahara, H., Gotoh, C., Choi K., Feng, D. D., Chen, C., Lee, H., Katoh, K., Roh, S., \& Sasaki, S. (2005). Acetate and propionate short chain fatty acids stimulate adipogenesis via GPCR43. Endocrinology, 146(12), 5092-5099.

Jan, G., Belzacq, A.-S., Haouzi, D., Rouault, A., Metivier, D., Kroemer, G., \& Brenner, C. (2002). Propionibacteria induce apoptosis of colorectal carcinoma cells via short-chain 
596

597

598

599

600

601

602

603

604

605

606

607

608

609

610

611

612

613

614

615

616

617

618

619

Jensen, N. S., \& Canale-Parola, E. (1986). Bacteroides pectinophilus sp. Nov. Bacteroides galacturonicus sp. Nov.: Two Pectinolytic Bacteria from the Human Intestinal Tract. Applied and Environmental Microbiology, 52(4), 880-887.

Kačuráková, M., Capek, P., Sasinková, V., Wellner, N., \& Ebringerová, A. (2000). FT-IR study of plant cell wall model compounds: pectic polysaccharides and hemicelluloses. Carbohydrate Polymers, 43(2), 195-203.

Kolida, S., \& Gibson, G. R. (2007). Prebiotic capacity of inulin-type fructans. The Journal of Nutrition, 137(11), 2503S-2506S.

Kurita, O., Fujiwara, T., \& Yamazaki, E. (2008). Characterization of the pectin extracted from citrus peel in the presence of citric acid. Carbohydrate Polymers, 74, 725-730.

Langendijk, P. S., Schut, F., Jansen, G. J., Raangs, G. C., Kamphuis, G. R., Wilkinson, M. H. F., \&Welling, G.W. (1995). Quantitative fluorescent in situ hybridisation of Bifidobacterium with genus- specific 16S rRNA-targeted probes and its application in fecal samples. Applied and Environmental Microbiology, 61, 3069-3075.

Liew, S. Q., Chin, N. L., Yusof, Y. A., \& Sowndhararajan, K. (2016). Comparison of Acidic and Enzymatic Pectin Extraction from Passion Fruit Peels and Its Gel Properties. Journal of Food Process Engineering, 39, 501-511.

Lu, Y., Zhang, M., Zhao, P., Jia, M., Liu, B., Jia, Q., Guo, J., Dou, L., \& Li, J. (2017). Modified citrus pectin inhibits galectin-3 function to reduce atherosclerotic lesions in apoE-deficient mice. Molecular Medicine Reports, 16, 647-653.

Manderson, K., Pinart, M., Tuohy, K. M., Grace, W. E., Hotchkiss, A. T., Widmer, W., Yadhav, M. O., Gibson, G. R. \& Rastall, R. A. (2005). In vitro determination of prebiotic properties of oligosaccharides derived from an orange juice manufacturing by-product stream. Applied and Environmental Microbiology, 71(12), 8383-8389. 
Manz, W., Amann, R., Ludwig, W., Vancanneyt, M., \& Schleifer, K. H. (1996). Application of a suite of $16 \mathrm{~S}$ rRNA-specific oligonucleotide probes designed to investigate bacteria of the phylum Cytophaga-Flavobacter-Bacteroides in the natural environment. Microbiology (Reading, England), 142, 1097-1106.

Maxwell, E. G., Belshaw, N. J., Waldron, K. W., \& Morris, V. J. (2012). Pectin - An emerging new bioactive food polysaccharide. Trends in Food Science and Technology, 24(2), 64-73.

Maxwell, E. G., Colquhoun, I. J., Chau, H. K., Hotchkiss, A. T., Waldron, K. W., Morris, V. J. and Belshaw N. J. (2015). Rhamnogalacturonan i containing homogalacturonan inhibits colon cancer cell proliferation by decreasing ICAM1 expression. Carbohydrate Polymers $132,546-553$.

Míguez, B., Gómez, B., Gullón, P., Gullón, B., \& Alonso, L. (2016). Pectic Oligosaccharides and Other Emerging Prebiotics. In V. Rao, \& L. G. Rao (Eds.), Prebiotics and Probiotics in Human Nutrition and Health (pp. 301-330). Spain, InTech.

Miller, T. L., \& Wolin, M. J. (1996). Pathways of acetate, propionate, and butyrate formation by the human fecal microbial flora. Applied and Environmental Microbiology, 62(5), 15891592.

Mohnen, D. (2008). Pectin structure and biosynthesis. Current Opinion in Plant Biology, 11(3), 266-277.

Morris, V. J., Belshaw, N. J., Waldron, K. W., \& Maxwell, E. G. (2013). The bioactivity of modified pectin fragments. Bioactive Carbohydrates and Dietary Fibre, 1, 21-37.

Muñoz-Almagro, N., Rico-Rodriguez, F., Villamiel, M., \& Montilla, A. (2018a). Pectin characterisation using size exclusion chromatography: A comparison of ELS and RI detection. Food Chemistry, 252, 271-276.

Muñoz-Almagro, N., Rico-Rodriguez, F., Wilde, P.J., Montilla, A., Villamiel. (2018b). Structural and technological characterization of pectin extracted with sodium citrate and 
646

647

648

649

650

651

652

653

654

655

656

657

658

659

660

661

662

663

664

665

666

667

668

669

Nangia-Makker, P., Hogan, V., Honjo, Y., Baccarini, S., Tait, L., Bresalier, R., \& Raz, A. (2002). Inhibition of human cancer cell growth and metastasis in nude mice by oral intake of modified citrus pectin. Journal of the National Cancer Institute, 94(24), 1854-1862.

Ngouémazong, E. D., Christiaens, S., Shpigelman, A., Van Loey, A., \& Hendrickx, M. (2015). The Emulsifying and Emulsion-Stabilizing Properties of Pectin: A Review. Comprehensive Reviews in Food Science and Food Safety, 14(6), 705-718.

Noreen, A., Nazli, Z. i. H., Akram, J., Rasul, I., Mansha, A., Yaqoob, N., Iqbal, R., Tabasum, S., Zuber, M., Zia, K. M. (2017). Pectins functionalized biomaterials; a new viable approach for biomedical applications: A review. International Journal of Biological Macromolecules, 101, 254-272.

Odun-Ayo, F., Mellem, J., \& Reddy, L. (2017). The effect of modified citrus pectin-probiotic on faecal lactobacilli in Balb/c mice. Food Science and Technology, 37(3), 478-482.

Olano-Martin, E., Mountzouris, K. C., Girbson, G. R. \& Rastall, R. A. (2001). Continuous Production of Pectic Oligosaccharides in an Enzyme Membrane Reactor. Food Engineering and Physical Properties, 66(7), 966-971.

Olano-Martin, E., Gibson, G. R., \& Rastall, R. A. (2002). Comparison of the in vitro bifidogenic properties of pectins and pectic-oligosaccharides. Journal of Applied Microbiology, 93(3), 505-511.

Onumpai, C., Kolida, S., Bonnin, E., \& Rastall, R. A. (2011). Microbial utilization and selectivity of pectin fractions with various structures. Applied and Environmental Microbiology, 77(16), 5747-5754.

Park, H. R., Park, S. B., Hong, H. Do, Suh, H. J., \& Shin, K. S. (2017). Structural elucidation of anti-metastatic rhamnogalacturonan II from the pectinase digest of citrus peels (Citrus unshiu). International Journal of Biological Macromolecules, 94, 161-169. 
Popov, S. V, \& Ovodov, Y. S. (2013). Polypotency of the immunomodulatory effect of pectins. Biochemistry (Moscow), 78(7), 823-835.

Ramachandran, C., Wilk, B., Melnick, S. J., \& Eliaz, I. (2017). Synergistic Antioxidant and Anti-Inflammatory Effects between Modified Citrus Pectin and Honokiol. Evidence-Based Complementary and Alternative Medicine, Vol. 2017(4), 1-9

Richardson, A. J., Calder, A. G., Stewart, C. S., \& Smith, A. (1989). Simultaneous determination of volatile and non-volatile acidic fermentation products of anaerobes by capillary gas chromatography. Letters in Applied Microbiology, 9, 5-8.

Sabater, C., Corzo, N., Olano, A., \& Montilla, A. (2018). Enzymatic extraction of pectin from artichoke (Cynara scolymus L.) by-products using Celluclast ${ }^{\circledR}$ 1.5L. Carbohydrate Polymers, 190, 43-49.

Samuelsson, L. M., Young, W. N., Fraser, K., Tannock, G. W., Lee, J., \& Roy, N. C. (2016). Digestive-resistant carbohydrates affect lipid metabolism in rats. Metabolomics, 12(5), 113.

Singthong, J., Cui, S. W., Ningsanond, S., \& Douglas Goff, H. (2004). Structural characterization, degree of esterification and some gelling properties of Krueo Ma Noy (Cissampelos pareira) pectin. Carbohydrate Polymers, 58(4), 391-400.

Vogt, L. M., Sahasrabudhe, N. M., Ramasamy, U., Meyer, D., Pullens, G., Faas, M. M., Venema, K., Schols, H. K. \& de Vos, P. (2016). The impact of lemon pectin characteristics on TLR activation and T84 intestinal epithelial cell barrier function. Journal of Functional Foods, 22, 398-407.

Wagner, M., Hornt, M., \& Daims, H. (2003). Fluorescence in situ hybridisation for the identification and characterisation of prokaryotes. Current Opinion in Microbiology, 6(3), 302-309. 

conventional heating extractions. Food Hydrocolloids, 61, 730-739.

697

Wikiera, A., Mika, M., Starzyńska-Janiszewska, A., \& Stodolak, B. (2015). Development of complete hydrolysis of pectins from apple pomace. Food Chemistry, 172, 675-680.

Yang, J., Martínez, I., Walter, J., Keshavarzian, A., \& Rose, D. J. (2013). In vitro characterization of the impact of selected dietary fibers on fecal microbiota composition and short chain fatty acid production. Anaerobe, 23, 74-81.

Yapo, B. M. (2009). Pectin quantity, composition and physicochemical behaviour as influenced by the purification process. Food Research International, 42, 1197-1202.

Yuliarti, O., Goh, K. K. T., Matia-Merino, L., Mawson, J., \& Brennan, C. (2015). Extraction and characterisation of pomace pectin from gold kiwifruit (Actinidia chinensis). Food Chemistry, 187, 290-296.

Zeng, H. (2014). Mechanisms linking dietary fiber, gut microbiota and colon cancer prevention. World Journal of Gastrointestinal Oncology, 6(2), 41-51.

Zhang, W., Xu, P., \& Zhang, H. (2015). Pectin in cancer therapy: A review. Trends in Food Science and Technology, 44(2), 258-271. 